\title{
Anti-inflammatory effects of avocado peels against inflammation induced by carrageenan in mice
}

\author{
Eko Aprilianto, Alexander Vito Harmoni Swastika Yuan, \\ Claudia Darantika Pradita, Phebe Hendra* \\ Department of Pharmacology and Toxicology, Faculty of Pharmacy, \\ Universitas Sanata Dharma
}

Submitted: 17-07-2019

Reviewed: 17-07-2019

Accepted: 05-10-2019

\begin{abstract}
The aim of this research is to investigate the anti-inflammatory activity of avocado peel against carrageenan-induced inflammation in mice. The group of mice that was used as a negative control group to test the anti-inflammatory activity of infusion and decoction (group I) were given aquadest, while the group for testing the activity of extract (group II) was given CMC-Na. The positive control group (group III) was given potassium diclofenac. Groups IV-VI were given avocado peel infusion with the following doses 667.5; 1335; and $2670 \mathrm{mg} / \mathrm{kgBW}$ respectively. Groups VII-IX were given avocado peel decoction with the same doses as the previous groups. Groups X-XII were given 830; 1670; and $3330 \mathrm{mg} / \mathrm{kgBW}$ of avocado peel extract respectively. The paw edema were measured using a digital caliper for 6 hours afterwards after carrageenan injection. There were a significant $(\mathrm{p}<0.05)$ reduction in paw edema at all doses of infusion, decoction, and extract of avocado peel. Based on the research, it can be concluded that the avocado peels have anti-inflammatory activities.
\end{abstract}

Keywords: avocado, peel, anti-inflammatory, carrageenan

*Coressponding author:

Phebe Hendra

Department of Pharmacology and Toxicology, Faculty of Pharmacy

Universitas Sanata Dharma

Email: phebe_hendra@usd.ac.id 


\section{INTRODUCTION}

Inflammation is the body's response to eliminate either foreign substances, pathogens, or irritants and manage tissue repairment (Karch, 2003). In inflammation, there is a process where free radicals are produced (Ardhie, 2011). Free radicals can cause tissue damage which triggers the biosynthesis of arachidonic acid, which were converted to prostaglandin as a mediator of inflammation. Common signs of inflammation are swelling, pain, redness, heat, and loss of function. These signs often cause discomfort for people so they need to be treated quickly (Supriyatna et al., 2015).

The bioactive contents of avocado showed higher antioxidant activities towards DPPH method (Malangngi et al., 2012). Antioxidants binds free radicals and inhibit the cyclooxygenase enzyme as the mechanism of inflammatory inhibition to prevent the production of prostaglandin. This will impact in the inhibition of inflammatory mediators. According to this thing, another research shows the existence of analgesic activity from avocado seed (Kyakulaga et al., 2012; Josephine and Ngozi, 2013). However, the research of anti-inflammation activity of avocado peel is never reported, although avocado peels have higher antioxidant activities and more bioactive contents such as phenolic compounds compared to avocado seeds. Based on those things, the research objective is to find out the anti-inflammation activity in infusion, decoction and extract of avocado peels on mice.

\section{MATERIAL AND METHODS}

\section{Plant material and chemicals}

Avocado peels were collected from Yogyakarta which were determined by the Department of Biology at the Faculty of Pharmacy of Gadjah Mada University, Yogyakarta. Aquadest, $\mathrm{NaCl} 0.9 \%$ solution, CMC-Na, Potassium diclofenac (Cataflam Fast ${ }^{\circledR}$ ) and Carrageenan (Sigma Chemical Company) were obtained from Pharmacology and Toxicology Laboratory of the Faculty of Pharmacy of Sanata Dharma University.

\section{Animal}

Adult male Swiss mice weighing 20-30 g were used for this experiment. All of mice were obtained from Imono Laboratory of the Faculty of Pharmacy of Sanata Dharma University.

\section{Preparation of Avocado Peel Extracts}

Each avocado peel infusion and avocado peel decoction were obtained by measuring dry powder of avocado peel $\pm 8 \mathrm{~g}$, then putting it in the infusion pan and mixing with $16 \mathrm{~mL}$ of aquadest. The next step, the infusion pan was heated with a hotplate with temperature of $90{ }^{\circ} \mathrm{C}$ within 15 minutes for the avocado peel infusion and 30 minutes for the avocado peel decoction. Each mixture was filtered using flannel cloth to obtain infusion and decoction of avocado peel respectively.

The dry powder of avocado peel $(50 \mathrm{~g})$ was extracted with methanol $(90 \% \mathrm{v} / \mathrm{v})$ for 24 hours at room temperature. The mixture was filtered using Buchner funnel, then concentrated by using rotary evaporator to yield a semi solid extract.

\section{Study Design}

This research has been approved by the Medical and Health Research Ethics Committee (MHREC) of Faculty of Medicine of Gadjah Mada University with approval number ref: $\mathrm{KE} / \mathrm{FK} / 0873 / \mathrm{EC} / 2017$. A total of 60 mice were divided randomly into 12 groups. Acute edema was induced by injection of carrageenan $1 \%$ into the sub-plantar region of hind-paw of mice (Chamundeeswari et al., 2004; Tjandrawinata et al., 2015). The mice of group I, as a negative control group for avocado peel infusion and decoction, were given aquadest. Group II, as negative control group for avocado peel extract, were given $\mathrm{CMC}-\mathrm{Na}$, and group III, as positive control, were given Cataflam Fast ${ }^{\circledR}$ (Pottasium Diclofenac) $4.48 \mathrm{mg} / \mathrm{kgBW}$. Groups IV - VI were given avocado peel infusion with 3 levels of doses, 667.5; 1335; and $2670 \mathrm{mg} / \mathrm{kgBW}$ (Kristanti et al., 2017). Groups VII - IX were given avocado peel decoction with 3 levels of doses which were $667.5 ; 1335$; and 2670 
$\mathrm{mg} / \mathrm{kgBW}$. Groups X - XII were given avocado peel extract with 3 levels of doses which were 830; 1670; and $3330 \mathrm{mg} / \mathrm{kgBW}$ (Kristanti et al., 2017).

Edema thickness in mice's paw was measured using digital caliper at $0,15,30,45,60,90,120$, $150,180,210,240,270,300,330$, and 360 minutes after carrageenan injection (Tjandrawinata et al., 2015; Hendra et al., 2017; Kristanti et al., 2017) using the equation as followed:

$$
\mathrm{Tu}=\mathrm{Tt}-\mathrm{To}
$$

Tu: Thickness of mice foot edema in particular time

Tt: Thickness of mice foot after $1 \%$ carrageenan induction

To: Thickness of mice foot before $1 \%$ carrageenan induction

The calculation of the edema volume was conducted using formula area under curve (AUC) and percentage of inhibition of inflammation (Boakye-Gyasi et al., 2008; Nguemfo et al., 2007; Chaulya et al., 2012). Area Under Curve (AUC) was calculated for each minute within 0-6 hours using trapezoid method formula. These are detailed as below:

$$
A U C_{t n-1}=\frac{T_{t n-1}-T_{t n}}{\left(t_{n}-t_{n-1}\right)}
$$

$\mathrm{T}_{\mathrm{tn}-1}$ : Average edema volume on $\mathrm{t}_{\mathrm{n}-1}$

$\mathrm{T}_{\mathrm{tn}}$ : Average edema volume on $\mathrm{t}_{\mathrm{n}}$

$$
\text { Inhibition of inflammation }(\%)=\frac{\left(A U C_{0-x}\right)_{0}-\left(A U C_{0-x}\right)_{n}}{\left(A U C_{0-x}\right)_{0}} \times 100 \%
$$

$\left(\mathrm{AUC}_{0-\mathrm{x}}\right)_{0}=$ average $\mathrm{AUC}_{0-\mathrm{x}}$ for negative control group,

$\left(\mathrm{AUC}_{0-\mathrm{x}}\right)_{\mathrm{n}}=\mathrm{AUC}_{0-\mathrm{x}}$ for each animal given test drug at dose of $\mathrm{n}$

\section{Statistical Analysis}

Total AUC value are expressed as mean \pm standard deviation (SD). Data were analyzed using one-way analysis of variance followed by post-hoc tests using SPSS 22. A p-value $<0.05$ was considered statistically significant. Statistical differences were determined using the Student's $t$-test, with $p$-values being indicated for each figure.

\section{RESULTS AND DISCUSSION}

The present study determines the anti-inflammatory activity of avocado peel against carrageenan-induced inflammation in mice. Carrageenan-induced paw edema has been commonly used for acute inflammation animal model. Inflammation induced by carrageenan was observed to have two phases, early phase (up to $2 \mathrm{~h}$ ) and late phase (1-6h) as shown at graph of negative control (Figure 1-3). The avocado peel showed a reduction in paw edema at all time interval. 


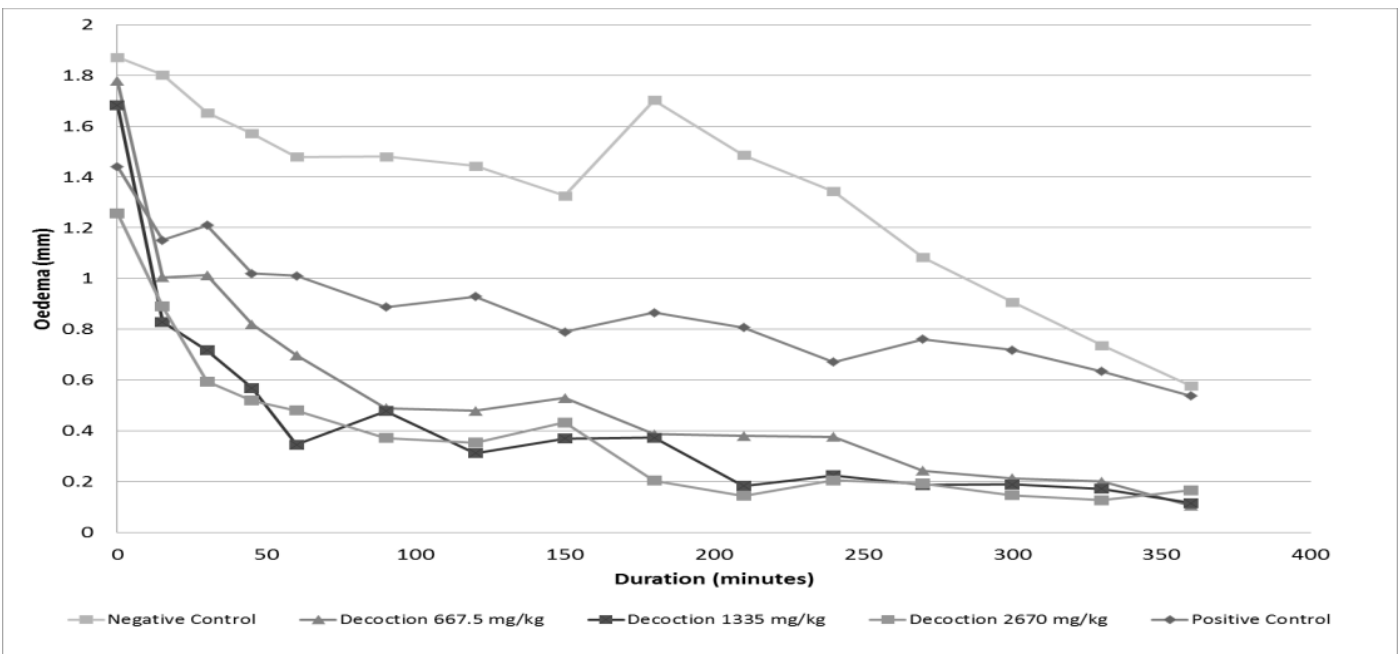

Figure 1. Graph of duration vs oedema thickness of avocado peel decoction

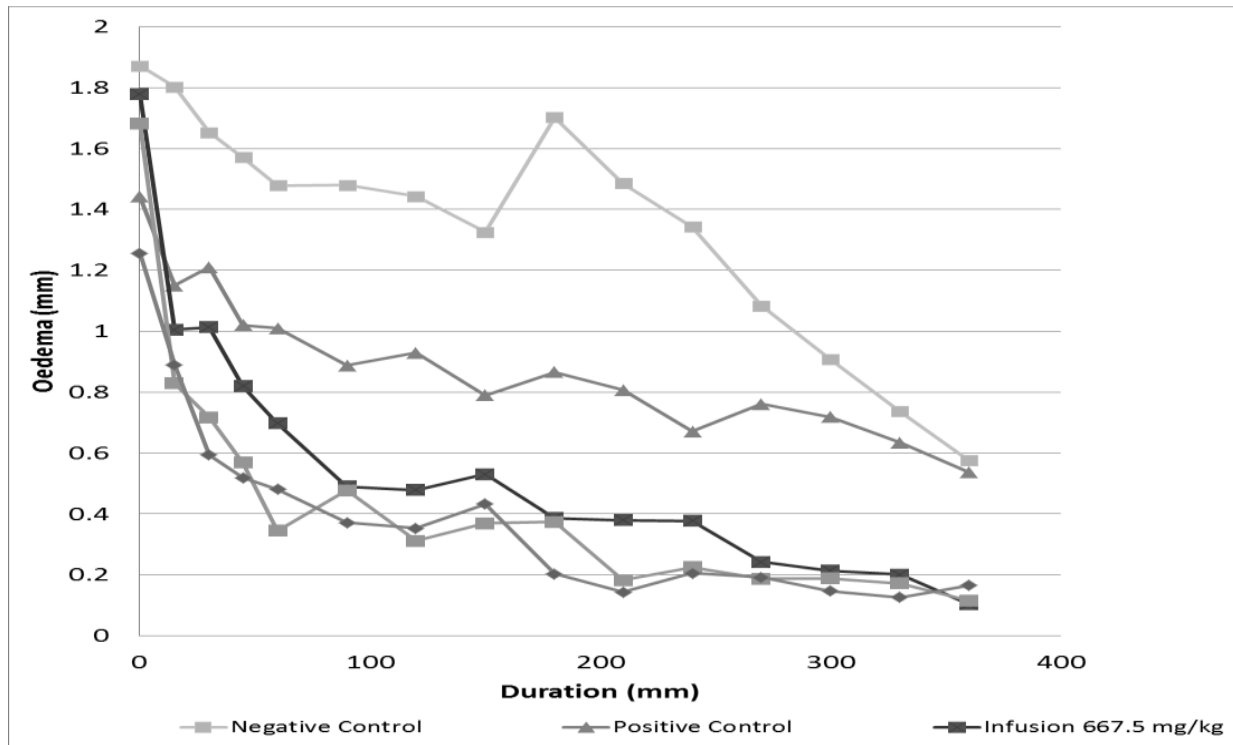

Figure 2. Graph of duration vs oedema thickness of avocado peel infusion 


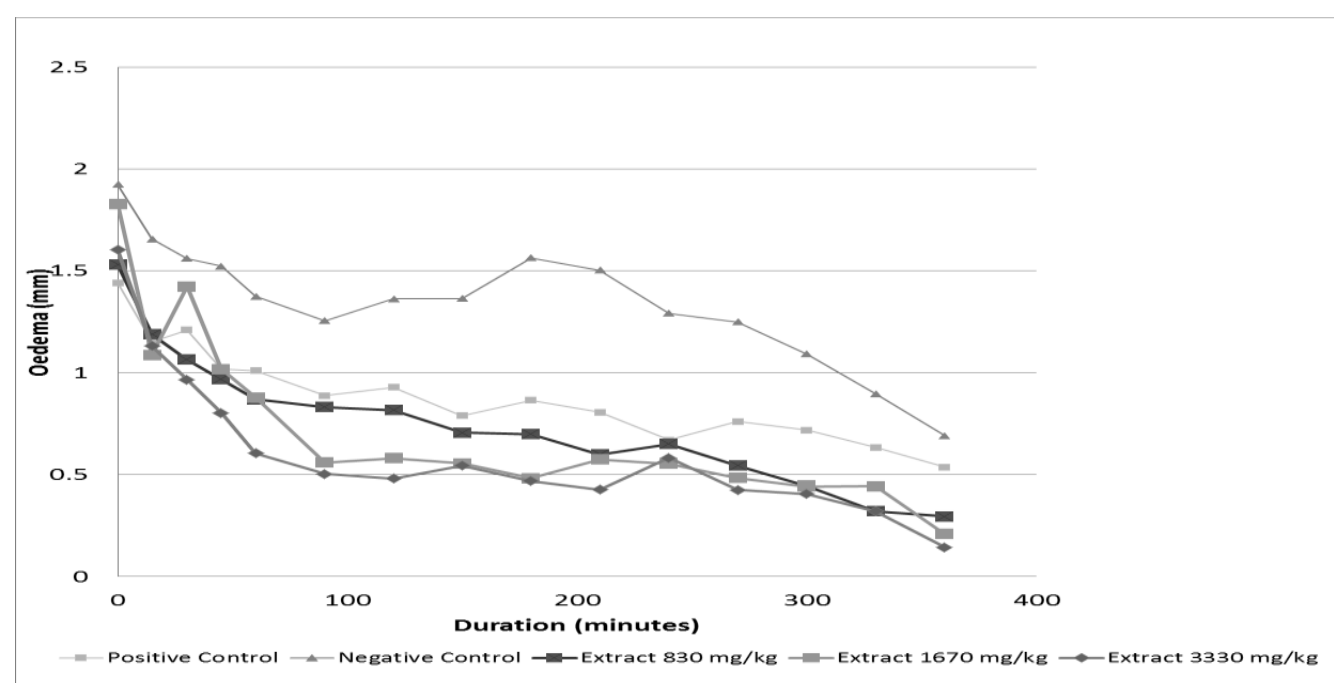

Figure 3. Graph of duration vs oedema thickness of avocado peel extract

In carrageenan-induced paw edema model, it was found that both avocado peel infusion and avocado peel decoction exhibited a significant inhibition $(\mathrm{p}<0.05)$ compared negative control aquadest on paw edema formation. Percentage inhibiton were 65.6, 72.0, and $75.2 \%$ at the doses $667.5 ; 1335$; and $2670 \mathrm{mg} / \mathrm{kgBW}$ of avocado peel infusion, while positive control potassium diclofenac was $47.7 \%$ (Table I). Avocado peel decoction also reduced paw edema compared negative control aquadest by $36.8,39.9,45.5 \%$ at the dose $667.5 ; 1335$; and $2670 \mathrm{mg} / \mathrm{kgBW}$ respectively. There were a reduction in paw edema significantly $(\mathrm{p}<0.05)$ at all doses of the extract in comparison to negative control CMC$\mathrm{Na}$ by $49.3,50.5$, and $58.6 \%$ at the doses $833 ; 1670$; and $3330 \mathrm{mg} / \mathrm{kgBW}$ respectively. All of the effects were non-dose dependent manner.

The results of this study showed that all doses levels of infusion, decoction and extract of avocado peels had a significant anti-inflammatory activity. The shorter extraction time by infusion (15min) showed the best activity compared decoction $(30 \mathrm{~min})$. This evidence strongly suggests that different types of extraction method and solvent had great influence on the anti-inflammatory property of avocado peels. However, it is not yet known exactly which class of compounds contained in avocado peels that are responsible for anti-inflammatory activity.

Table I. Effect of avocado peels on carrageenan-induced mice

\begin{tabular}{lcc}
\hline \multicolumn{1}{c}{ Group } & AUC (mm.minute) & \% Inhibition \\
\hline Negative control (aquadest) & $476.59 \pm 7.25^{\mathrm{b}}$ & $0 \pm 1.5$ \\
Negative control (CMC-Na) & $474.34 \pm 7.99^{\mathrm{b}}$ & $0 \pm 1.7$ \\
Positive control (potassium diclofenac 4,48 mg/kg BW) & $249.11 \pm 7.80^{\mathrm{a}, \mathrm{c}}$ & $47.7 \pm 1.6$ \\
Avocado Peel Infusion 667.5 mg/kg BW & $163.76 \pm 12.21^{\mathrm{a}, \mathrm{b}}$ & $65.6 \pm 2.6$ \\
Avocado Peel Infusion 1335 mg/kg BW & $133.42 \pm 7.56^{\mathrm{a}, \mathrm{b}}$ & $72.0 \pm 1.6$ \\
Avocado Peel Infusion 2670 mg/kg BW & $118.25 \pm 8.37^{\mathrm{a}, \mathrm{b}}$ & $75.2 \pm 1.8$ \\
Avocado Peel Decoction 667.5 mg/kg BW & $301.24 \pm 5.97^{\mathrm{a}, \mathrm{b}}$ & $36.8 \pm 1.3$ \\
Avocado Peel Decoction 1335 mg/kg BW & $286.69 \pm 7.10^{\mathrm{a}, \mathrm{b}}$ & $39.9 \pm 1.5$ \\
Avocado Peel Decoction 2670 mg/kg BW & $259.96 \pm 2.29^{\mathrm{a}}$ & $45.5 \pm 0.5$ \\
Avocado Peel Extract 833 mg/kg BW & $240.34 \pm 6.04^{\mathrm{c}}$ & $49.3 \pm 1.3$ \\
Avocado Peel Extract 1670 mg/kg BW & $234.72 \pm 9.83^{\mathrm{c}}$ & $50.5 \pm 2.1$ \\
Avocado Peel Extract 3330 mg/kg BW & $196.32 \pm 17.98^{\mathrm{b}, \mathrm{c}}$ & $58.6 \pm 3.8$ \\
\hline Val &
\end{tabular}

Values are expressed as mean \pm SD of five animals in each group; a: $p<0.05$ vs aquadest negative control; b: $p<0.05$ vs positive control; c: $p<0.05$ vs CMC-Na negative control 
The results obtained in the rat paw edema show that the active principles present in the avocado peel may act analogously in the inflammatory response produced by carrageenan. These results are similar with a previous report in which the same doses of avocado seed infusion and extract had antiinflammatory activities (Kristanti et al., 2017). Avocado leaves also possess anti-inflammatory activity (Adeyemi et al., 2002).

The phytochemical screening of avocado peel showed the presence of flavonoid (Vinha et al., 2013) and these antioxidants might contribute as anti-inflammatory that is able to capture free radicals that cause the emergence of inflammatory responses (Rodriguez-Carpena et al., 2011; Kosinska et al., 2012; Arukwe et al., 2012). The flavonoid mechanism of stabilizing reactive oxygen species (ROS) is reacting with the reactive compound of the radicals so that the radicals become inactive (Pourmourad et al., 2006). Flavonoids have been determined to produce anti-inflammation effect by suppressing the lipoxygenase and/or cyclo-oxygenase activities. The above results on anti-inflammatory of avocado peels corresponds to these findings. However, the specific of flavonoid of avocado peel has not been determined.

\section{CONCLUSION}

Avocado peel can represent a useful source of anti-inflammatory activity in dose dependent manner. Further studies involving the isolation of anti-inflammatory compounds is needed.

\section{REFERENCES}

Adeyemi, O.O., Okpo, S.O., Ogunti, O.O., 2002. Analgesic and anti-inflammatory effects of the aqueous extract of leaves of Persea Americana Mill ( Lauraceae), Fitoterapia, 73: 375-380.

Ardhie, A.M., 2011. Radikal Bebas dan Peran Antioksidan dalam Mencegah Penuaan, Medicinus, 24(1), 4-9.

Arukwe, U., Amadi, B., Duru, M., Agommo, E.N., Adindu, E.A., Odika, P.C., Lele, K.C., Egejuru, L., dan Anudike, J., 2012. Chemical Composition of Persea americana Leaf, Fruit and Seed, IJRRAS, 11(2): 346-349.

Boakye-Gyasi E,. Woode E., Ainooson, G.K., Obiri, D.D., Ansah, C., Duwejua, M., Donkoh, A., 2008. Anti-inflammatory and Antipyretic Effects of Ethanolic Extract of Palisota hirsuta K. Schum Roots, African Journal of Pharmacy and Pharmacology, 2 (9): 191-199.

Chamundeeswari, D., Vasantha, J., Gopalakrishnan, S., Sukumar, E., 2004. Anti-inflammatory and Antinociceptive Activities of Trewia polycarpa Roots, Fitoterapia, 75(8): 740-744.

Chaulya, N.C., Haldar, P.K., Mukherjee. A., 2012. Anti-inflammatory and Analgesic Activity of Methanol Extracts of Cyperus tegetum Roxb. Rhizome, Journal of PharmaSciTech, 1(2): 27-29.

Joshepine, O.O., and Ngozi, A.O., 2013. Analgesic Effect of The Aqueous Extract of Persea americana Mill (Lauraceae), Journal of Pharmaceutical and Allied Sciences, 10(3), 1887-1897.

Hendra, P., Fenty, Andreani, P.R., Pangestuti, B.M.E., Julianus, J., 2017. Evaluation of Antihyperlipidemic, Anti-inflammatory, and Analgesic Activities of Eurycoma longifolia in Animal Models. International Journal of Pharmacy and Pharmaceutical Sciences, 9(3): 166169.

Karch, A.M., 2003. Focus on Nursing Pharmacology, $2^{\text {nd }}$ Edition. New York, Lippincott Williams and Wilkins, 659-660.

Kosinska, A., Karamac, M., Estrella, I., Hernandez, T., Bartolome, B., dan Dykes, G.A., 2012. Phenolic Compound Profiles and Antioxidant Capacity of Persea americana Mill. Peels and Seeds of Two Varieties. Journal of Agriculture and Food Chemistry. 60(18): 4613-4619. 
Kristanti, C.D., Simanjuntak, F.P.J., Dewi, N.K.P.A., Tianri, S.V., Hendra, P., 2017. Antiinflammatory and Analgesic Activities of Avocado Seed (Persea Americana Mill.), Jurnal Farmasi Sains dan Komunitas, 14(2): 104-111.

Kyakulaga, AI.,H., Ogwang, P.E., Nannyonga, S., Nyafuono, J., and Tumuslime, R., 2012. Antipyretic and Analgesics Activities of Ethanolic Extract of Persea americana Mill. Seeds in Wistar Albino Rats. Africa Journal of Animal and Biomedical Sciences, 7(1): 19-23.

Malangngi, L.P., Sangi, M.S., dan Paendong J.J.E., 2012. Penentuan Kandungan Tanin dan Uji Aktivitas Antioksidan Ekstrak Biji Buah Alpukat (Persea americana Mill.). Jurnal Kimia FMIPA Unsrat, 1(1): 5-10.

Nguemfo, E.L., Dimo, T., Azebaze, A.G.B., Asongalem, E.A., Alaoui, K., Dongmo, A.B., Cherrah, Y., Kamtchouing, P., 2007. Anti-inflammatory and Anti-nociceptive Activities of The Stem Bark Extract from Allanblackia monticola STANER L.C. (Guttiferae), Journal of Ethnopharmacology, 114(3): 417-424.

Pourmourad, F., Hosseinimehr, S.J., Shahabimajd, N., 2006. Antioxidant Activity, Phenol and Flavonoid Contents of Some Selected Iranian Medicinal Plants, African Journal of Biotechnology, 5(11): 1142-1145.

Rodriguez-Carpena, J.G., Morcuende, D., Andrade, M.J., Kylli, P., dan Estevez, M., 2011. Avocado (Persea americana Mill.) Phenolics, in vitro Antioxidant and Antimicrobial Activities, and Inhibition of Lipid and Protein Oxidation in Porcine Patties. Journal of Agriculture and Food Chemistry, 59(10): 5625-5635.

Supriyatna, Febriyanti, R., Dewanto, Wijaya, I., dan Ferdiansyah, F., 2015. Fitoterapi Sistem Organ: Pandangan Dunia Barat terhadap Obat Herbal Global, Ed. 2, Cet. 2, CV Budi Utama, Yogyakarta, 223-224.

Tjandrawinata R.R., Djunarko, I., Fenty, Hendra, P., 2015. Anti-inflammation Effects of Bioactive Fraction DLBS0533 Containing Phaleria Macrocarpa and Nigella Sativa on Animal Model, Journal of Pharmacy and Pharmaceutical Sciences, 7(1): 408-411.

Vinha, A.F., Moreira, J., and Barreira, S.V.P., 2013. Physicochemical Parameters, Phytochemical Composition and Antioxidant Activity of the Algarvian Avocado (Persea americana Mill.), Journal of Agricultural Science, 5 (12): 100-109. 
Pharmaciana Vol. 9, No. 2, Nov 2019, Page. 219-226 